\title{
BRPKM
}

Buletin Riset Psikologi dan Kesehatan Mental

http://e-journal.unair.ac.id/index.php/BRPKM

e-ISSN: 2776-1851

ARTIKEL PENELITIAN

\section{Hubungan Body Dissatisfaction dengan Depresi pada Remaja dengan Obesitas pada Masa Pandemi COVID-19}

\author{
NURUL AWALIYAH HASTANTI RAHAYU \& ATIKA DIAN ARIANA* \\ Fakultas Psikologi Universitas Airlangga
}

\begin{abstract}
ABSTRAK
Penelitian ini memiliki tujuan untuk mengetahui hubungan antara ketidakpuasan tubuh dengan depresi pada remaja dengan obesitas pada masa pandemik COVID-19. Ketidakpuasan tubuh memiliki dampak negatif yang telah diidentifikasi sebagai prediktor masalah psikologis salah satunya adalah mood depresi. Penelitian ini menggunakan pendekatan kuantitatif dengan metode survei. Partisipan pada penelitian ini melibatkan 42 remaja, dengan rentang usia 10-21 tahun dan Indeks Massa Tubuh 30 atau lebih. Alat ukur yang digunakan yaitu Skala Ketidakpuasan Tubuh dan Skala Depresi Center for Epidemiologi Studies Depression Scale Revised (CESD-R). Hasil dari analisis menunjukkan bahwa terdapat hubungan yang positif antara ketidakpuasan tubuh dengan depresi pada remaja dengan obesitas $(r=0,642, p=0,000)$. Dapat ditarik kesimpulan bahwa semakin tinggi ketidakpuasan tubuh maka semakin tinggi kecenderungan depresi pada remaja dengan obesitas pada masa pandemi COVID-
\end{abstract} 19.

Kata kunci: covid-19, depresi, ketidakpuasan tubuh, obesitas

\begin{abstract}
This study aimed to know the relationship between body dissatisfaction and depression in adolescents with obesity during the COVID-19 pandemic. Body dissatisfaction had a negative effect which had been identified as a predictor of psychological problems, one of which was depression. The study used a quantitative approach with a survey method. The study involved 42 adolescents, obese adolescents, with an age range of $10-21$ years and a Body Mass Index of 30 or more. The instrument used the Body Dissatisfaction Scale and Depression Scale Center for Epidemiology Studies Depression Scale-Revised (CESD-R). The result of the study showed that there was a positive relationship between body dissatisfaction and depression in obese adolescents $(r=0,642, p=0,000)$. It can be concluded that the higher the body dissatisfaction, the more the tendency of depression in obese adolescents during the COVID-19 pandemic.
\end{abstract}

Keywords: body dissatisfaction, covid-19, depression, obesity

Buletin Penelitian Psikologi dan Kesehatan Mental (BRPKM), 2021, Vol. 1(2), 1420-1426

*Alamat korespondensi: Fakultas Psikologi Universitas Airlangga, Kampus B Universitas Airlangga Jalan Airlangga 4-6 Surabaya 60286. Surel: atika.ariana@psikologi.unair.ac.id

Naskah ini merupakan naskah dengan akses terbuka dibawah ketentuan the Creative Common Attribution License (CC-BY-4.0) (http://creativecommons.org/licenses/by/4.0), 
sehingga penggunaan, distribusi, reproduksi dalam media apapun atas artikel ini tidak dibatasi, selama sumber aslinya disitir dengan baik.

\section{PENDAHULUAN}

Remaja merupakan masa dimana mereka mulai memperhatikan tubuh mereka dan mengembangkan gambaran seperti apa tubuh mereka. Kesibukan dengan citra tubuh mereka sangat kuat selama masa remaja. Perbedaan gender pada remaja mencirikan persepsi yang berbeda mengenai tubuh mereka. Telah ditemukan pada perempuan bahwa internalisasi tubuh kurus sebagai tubuh ideal menjadi prediktor peningkatan ketidakpuasan tubuh (Presnell, Bearman, \& Stice, 2004). Saat masa pubertas berlangsung remaja perempuan sering kali tidak puas dengan tubuh mereka, hal tersebut disebabkan karena lemak pada tubuh mereka yang meningkat. Obesitas disebutkan memiliki korelasi dengan pubertas dini pada anak perempuan dan pubertas yang tertunda pada anak laki-laki (Hazen, Schlozman, \& Beresin, 2008).

Remaja laki-laki cenderung lebih puas ketika telah melewati masa pubertas dikarenakan massa otot meningkat. Namun, internalisasi tubuh ideal pada remaja laki-laki juga dapat menyebabkan ketidakpuasan tubuh karena perbedaan tubuh ideal dan tubuh yang sebenarnya dapat menyebabkan tekanan tubuh. Ketika remaja laki-laki secara objektif mengalami kelebihan berat badan mereka akan menjadi khawatir (Presnell, Bearman, \& Stice, 2004). Obesitas sendiri merupakan akumulasi dari lemak dalam tubuh manusia yang melebihi jumlah yang dibutuhkan untuk fungsi tubuh normal, akumulasi secara terus menerus inilah yang menghasilkan kenaikan berat badan (Maria \& Evagelia, 2009).

Obesitas juga masih menjadi permasalahan kesehatan di dunia, bahkan WHO (2017) menyatakan bahwa obesitas merupakan masalah epidemic global. Sedangkan, di Indonesia berdasarkan hasil data yang diperoleh oleh Kementerian Kesehatan Badan Penelitian dan Pengembangan Kesehatan (2018) menyatakan bahwa proporsi berat badan obesitas pada usia $>18$ tahun dengan indikator IMT $\geq 27,0$ dari tahun 2007-2018 mengalami peningkatan. Pada tahun 2007 remaja dengan obesitas sebanyak 10.5\%, kemudian pada tahun 2013 meningkat menjadi 14.8\%, dan pada tahun 2018 meningkat menjadi $21.8 \%$.

Pandemi COVID-19 remaja lebih sering menghabiskan waktu dirumah termasuk kegiatan pembelajaran. Hal ini menyebabkan meningkatnya perilaku makan, sehingga menyebabkan bertambahnya berat badan. Penelitian yang dilakukan oleh Zachary, dkk. (2020) pada 111 subjek dengan usia lebih dari 18 tahun pada masa karantina mandiri, menunjukkan 20\% sampel mengalami pertambahan berat badan sebanyak 5-10 pon (2,5-5 kg). Sejalan dengan penelitian sebelumnya, hasil dari penelitian yang dilakukan oleh Mustofa, dkk. (2021) pada 44 responden, menunjukkan bahwa 25 responden $(56,8 \%)$ mengalami kenaikan berat badan selama masa pandemi COVID-19. Survei yang dilakukan oleh Center for Disease Control and Prevention (CDC) pada 1.478 pasien di Amerika Serikat teridentifikasi positif Covid-19 mulai dari 1-30 Maret 2020, menunjukkan hasil bahwa penyakit penyerta yang memiliki prevalensi tertenggi yaitu hipertensi $(49,7 \%)$, kemudian diikuti oleh obesitas dengan (48,3\%) (Center for Disease Contol and Prevention, 2021). 
Obesitas juga berkaitan dengan masalah kesehatan mental (Santrock, 2011). Telaah literatur yang menunjukkan bahwa individu yang obesitas memiliki ketidakpuasan tubuh yang tinggi (Heinberg \& Thompson, 2009; Smolak \& Thompson, 2009 dalam Harriger \& Thompson, 2012). Obesitas diketahui menyebabkan peningkatan resiko konsekuensi psikososial negatif diantaranya adalah ketidakpuasan tubuh (body dissatisfaction) yang tinggi, self-esteem yang rendah, depresi, dan gangguan makan (Harriger \& Thompson, 2012).

Ketidakpuasan tubuh atau body dissatisfaction merupakan penilaian negatif individu terhadap bagian tubuh tertentu (Presnell, Bearman, \& Stice, 2004). Ketidakpuasan tubuh dipengaruhi oleh faktor sosiokultural, faktor biologis, dan faktor interpersonal. Selain itu keterkaitan antara ketidakpuasan tubuh dengan depresi dikarenakan adanya tekanan mengenai pentingnya tubuh kurus dan standar kecantikan lain yang tidak dapat dicapai sehingga hal tersebut dapat memunculkan efek negatif dari ketidakpuasan tubuh tersebut (Chen, Guo, \& Xiao, 2015). Dampak dari ketidakpuasan tubuh berdasarkan penelitian studi longitudinal salah satunya adalah mood depresi (Paxton, NeumarkSztainer, Hannan, \& Eisenberg, 2006; Stice, Hayward, Cameron, Killen, Taylor, 2000 dalam Chen, Guo, \& Xiao, 2015).

Depresi diartikan dengan adanya suasana hati yang sedih, hampa, atau mudah tersinggung, disertai dengan perubahan somatik dan kognitif yang secara signifikan memengaruhi kapasitas individu untuk berfungsi (APA, 2013). Depresi merupakan masalah kesehatan mental yang signifikan. Data menunjukkan bahwa wilayah Asia Tenggara memiliki kasus depresi tertinggi yaitu sebesar 27\% jika dibandingkan dengan wilayah Afrika, Mediterania Timur, Eropa, Amerika, dan Pasifik Barat. Indonesia yang merupakan bagian dari Asia Tenggara memiliki total kasus sebanyak 9.162 .886 atau 3,7\% dari populasi (World Health Organization, 2017). Prevalensi dari penderita depresi usia $\geq 15$ sebesar 6,1\% dari populasi (Kementerian Kesehatan Badan Penelitian dan Pengembangan Kesehatan, 2018). Dari data prevalensi penderita depresi di Indonesia menurut Riskesdas 2018 hanya 9\% yang meminum obat atau menjalani pengobatan medis dan $91 \%$ sisanya tidak.

Depresi secara signifikan memiliki kaitan dengan COVID-19 (Rajkumar, 2021). Terdapat penelitian yang menemukan bahwa 80\% dari kasus COVID-19 berkaitan dengan masalah psikologis, dan sisanya berkaitan dengan masalah kesehatan fisik (Winurini, 2020). Berdasarkan dari survei yang dilakukan oleh Perhimpunan Dokter Spesialis Kedokteran Jiwa Indonesia (PDSKJI) (2020 dalam Winurini, 2020), terhadap 1.552 responden, hasil menunjukkan 63\% dari responden mengalami kecemasan, dan 66\% responden mengalami depresi yang diakibatkan oleh pandemi COVID-19. Berdasarkan tinjauan literatur yang telah dijelaskan di atas, peneliti ingin mencari tahu lebih lanjut hubungan ketidakpuasan tubuh dengan depresi pada remaja dengan obesitas.

\section{Desain Penelitian}

\section{METODE}

Penelitian ini menggunakan pendekatan kuantitatif. Pendekatan kuantitatif adalah pendekatan yang menggunakan cara berpikir deduktif, yang berawal dari konsep setelah itu diukur secara empiris dengan tepat dan akurat. Metode yang digunakan, yaitu survei yang bertujuan untuk menanyakan 
responden mengenai kepercayaan mereka, opini, karakteristik, dan perilaku masa lalu ataupun saat ini (Neuman, 2007).

Partisipan

Partisipan dalam penelitian ini yaitu remaja laki-laki dan perempuan, dengan rentang usia 10-21 tahun, dan penderita obesitas dengan BMI $30 \mathrm{~kg} / \mathrm{m}^{2}$ atau lebih. Penelitian ini menggunakan non-probability sampling, yaitu ukuran sampel yang tidak diketahui dan memiliki pengetahuan yang terbatas mengenai kelompok atau populasi yang lebih besar darimana sampel diambil (Neuman, 2007). Populasi pada penelitian ini tidak diketahui, sehingga peneliti menggunakan batas minimal sampel yang harus didapatkan sebesar 40 partisipan. Partisipan yang didapatkan pada penelitian ini sejumlah 42 orang, yang sesuai dengan kriteria yang telah ditentukan.

\section{Pengukuran}

Pengukuran ketidakpuasan tubuh (body dissatisfaction) menggunakan skala ketidakpuasan tubuh yang diadopsi dari skala yang telah dibuat oleh Susanti (2015) yang terdiri dari 30 aitem. Skala ketidakpuasan tubuh ini dibentuk berdasarkan indikator ketidakpuasan yang dikemukakan oleh Rosen, Reiter, \& Orosan, 1995. Penilaian jawaban untuk pertanyaan favourable $(1=$ "sangat tidak setuju", 4="sangat setuju") dan untuk pertanyaan unfavourable (4="sangat tidak setuju", 1="sangat setuju"). Alat ukur untuk mengukur depresi menggunakan skala skala Center for Epidemiologi Studies Depression Scale Revised (CESD-R) yang telah diadaptasi oleh Danisati (2018). Skala tersebut berdasarkan pada teori yang dikemukakan oleh Radlolf pada tahun 1997, yang mengacu pada DSM-IV. Skala ini terdiri dari 19 aitem favourable. Pemberian skor untuk jawaban "kurang dari satu hari" yaitu 1, "1-2 hari” yaitu 2, "3-4 hari” yaitu 3, "5-7 hari” yaitu 4, dan untuk "hampir setiap hari selama 2 minggu” yaitu 5.

Teknik valitiditas penelitian ini menggunakan content validity, yaitu dibantu oleh professional judgement. Uji reliabilitas dilakukan dengan menggunakan teknik Cronbach's alpha yang dihitung menggunakan program IBM SPSS Statistic 22 for windows. Hasil uji reliabilitas ketidakpuasan tubuh adalah $\alpha=0,915$. Hasil uji reliabilitas Center for Epidemiologi Studies Depression Scale Revised (CESD-R) adalah $\alpha=0,924$. Dapat ditarik kesimpulan kedua alat ukur tersebut memiliki reliabilitas yang tinggi.

\section{Analisis Data}

Analisis penelitian ini menggunakan uji korelasi. Uji normalitas yang dilakukan menggunakan pendekatan Kolmogorov-Smirnov, kemudian dilakukan uji linearitas. Kemudian, uji korelasi yang dilakukan menggunakan pendekatan uji korelasi Pearson, untuk menggambarkan kekuatan dan arah hubungan linier antara dua variabel. Seluruh analisis menggunakan program IBM SPSS Statistic 22 for windows.

\section{HASIL PENELITIAN}

Hasil analisis statistik deskriptif variabel ketidakpuasan tubuh partisipan sebesar $(M=72,19, S D=18,749$, $M a x=10, M i n=42)$. Sedang untuk variabel depresi sebesar $(M=33,63, S D=14,999, M a x=82, M i n=19)$. Hasil analisis juga menunjukkan bahwa mayoritas partisipan mempunyai ketidakpuasan tubuh pada kategori sedang (60\%). Sejumlah 11 partisipan mempunyai ketidakpuasan tubuh pada kategori tinggi dan 6 partisipan (14\%) mempunyai ketidakpuasan tubuh pada kategori rendah. Sementara itu, hasil uji analisis deskriptif pada depresi menunjukkan bahwa sejumlah 34 (81\%) partisipan mempunyai tingkat depresi sedang, dan 8 (19\%) partisipan mempunyai depresi pada tingkat tinggi, dan tidak ada yang memiliki depresi pada kategori rendah. 
Nilai skewness pada ketidakpuasan tubuh menunjukkan skor 0,279 yang artinya nilai skor rendah dan mengelompok ke kiri. Nilai skewness pada depresi menunjukkan skor 1,379 yang artinya nilai skor rendah dan mengelompok ke kiri. Kurtosis ketidakpuasan tubuh menunjukkan skor -1,218 yang artinya berada di bawah 0 dan memiliki distribusi yang relatif datar. Sedangkan pada kurtosis depresi menunjukkan skor 1,588 yang artinya memiliki nilai positif dan sebarannya bergerombol di tengah.

Hasil analisis uji korelasi menunjukkan adanya hubungan positif yang signifikan antara ketidakpuasan tubuh dengan depresi, $(r=0,642, p=0,000)$. Artinya, semakin tinggi tingkat ketidakpuasan maka semakin tinggi tingkat depresi, dan sebaliknya.

\section{DISKUSI}

Penelitian ini memiliki tujuan untuk mengukur ada tidaknya hubungan ketidakpuasan tubuh dengan depresi pada remaja dengan obesitas pada masa pandemi COVID-19. Berdasarkan dari hasil analisis yang telah dilakukan, menunjukkan bahwa terdapat hubungan yang positif antara ketidakpuasan tubuh dan depresi pada remaja dengan obesitas pada masa pandemi COVID-19. Semakin tinggi ketidakpuasan tubuh maka semakin tinggi pula kecenderungan depresi pada remaja dengan obesitas pada masa COVID-19. Hal tersebut dikarenakan selama masa pandemi COVID-19 remaja banyak menghabiskan waktunya di rumah, menyebabkan peningkatan perilaku makan selama masa karantina dan menimbulkan peningkatan obesitas selama masa pandemi COVID-19. Sejalan dengan penelitian tersebut, ditemukan bahwa pada masa karantina mandiri menunjukkan responden meningkatkan makan sebagai respons terhadap stres, meningkatkan makan ketika mereka merasa bosan, meningkatkan makan makanan ringan setelah makan malam (Zachary, dkk., 2020). Penelitian yang dilakukan oleh Mustofa, dkk. (2021) dari 44 responden, menunjukkan 25 responden (56,8\%) mengalami kenaikan berat badan selama masa pandemi COVID-19.

Obesitas menyebabkan peningkatan resiko dari konsekuensi psikososial negatif diantaranya adalah ketidakpuasan tubuh (body dissatisfaction) yang tinggi, self-esteem yang rendah, depresi, dan gangguan makan (Harriger \& Thompson, 2012). Sejalan dengan teori yang dikemukakan oleh Santrock (2011) yang menyatakan bahwa obesitas juga berkaitan dengan masalah kesehatan mental. Pernyataan tersebut didukung dengan tinjauan literatur secara luas yang dilakukan oleh Heinberg \& Thompson (2009) dan Smolak \& Thompson (2009, dalam Harriger \& Thompson, 2012) yang menunjukkan bahwa pada individu yang obesitas secara signifikan memiliki ketidak puasan tubuh yang tinggi.

Remaja obesitas yang mengalami ketidakpuasan tubuh dikarenakan adanya tekanan mengenai pentingnya memiliki tubuh yang kurus dan juga adanya standar kecantikan lain yang tidak dapat dicapai (Chen, Guo, Xiao, 2015) menyebabkan individu merasa tidak puas dengan tubuhnya. Situasi tersebut dapat memicu reaksi psikologi seseorang yang mana mereka akan merasa tidak puas dengan dirinya. Perasaan tersebut dapat mengarahkan mereka kepada perasaan tertekan, sehingga dapat menimbulkan depresi pada individu. Efek negatif ketidakpuasan tubuh telah diidentifikasi sebagai prediktor masalah psikologis yang mana salah satunya adalah mood depresi (Paxton, Neumark-Sztainer, Hannan, \& Eisenberg, 2006; Stice, Hayward, Cameron, Killen, Taylor, 2000 dalam Chen, Guo, \& Xiao, 2015). Pernyataan tersebut dapat diartikan bahwa ketidakpuasan tubuh dapat mengakibatkan depresi pada remaja. 


\section{SIMPULAN}

Berdasarkan hasil analisis dari penelitian ini, dapat ditarik kesimpulan bahwa hipotesis alternatif $\left(\mathrm{H}_{\mathrm{a}}\right)$ diterima dan hipotesis null $\left(\mathrm{H}_{0}\right)$ ditolak. Hasil dari uji korelasi pearson menunjukkan bahwa terdapat hubungan yang signifikan antara ketidakpuasan tubuh dengan depresi pada remaja dengan obesitas pada masa pandemi COVID-19. Hasil uji korelasi yang positif menjelaskan bahwa semakin tinggi ketidakpuasan tubuh maka semakin tinggi pula kecenderungan depresi pada remaja dengan obesitas.

\section{UCAPAN TERIMAKASIH}

Terima kasih kepada Ibu Atika Dian Ariana, S.Psi., M.Sc., selaku dosen pembimbing skripsi, kepada Ali Hasanudin dan Yulianti selaku kedua orang tua penulis, kepada keluarga besar penulis, dan kepada seluruh sahabat penulis.

\section{DEKLARASI POTENSI TERJADINYA KONFLIK KEPENTINGAN}

Nurul Awaliyah Hastanti Rahayu dan Atika Dian Ariana tidak bekerja, menjadi konsultasn, memiliki saham, atau menerima dana dari perusahaan atau organisasi manapun yang mungkin akan mengambil untuk dari diterbitkannya naskah ini.

\section{PUSTAKA ACUAN}

APA. (2013). Diagnostic of Statistical Manual of Mental Disorders: Fifth Edition. American Psychiatric Publishing.

Center for Disease Control and Prevention (2021). Hospitalization Rates and Characteristics of Patients Hospitalized with Laboratory-Confirmed Coronavirus Disease 2019 - COVID-NET, 14 States, March 1-30, 2020. MMWR Morb Mortal Wkly Rep 2020, 69, 458-464. DOI: http://dx.doi.org/10.15585/mmwr.mm6915e3external icon

Chen, G., Guo, G., Gong, J., \& Xiao, S. (2015). The association between body dissatisfaction and depression: An examination of the moderating effects of gender, age, and weight status in a sample of chinese adolescents. Journal of Psychologists and Counsellors in Schools, 25(2), 245-260. https://doi.org/10.1017/jgc.2015.6

Danisati, S. (2018). Hubungan antara Self Compassion dan Depresi pada Remaja dari Keluarga Bercerai [Universitas Islam Indonesia]. https://dspace.uii.ac.id/handle/123456789/8001

Harriger, J. A., \& Thompson, J. K. (2012). Psychological consequences of obesity: Weight bias and body image in overweight and obese youth. International Review of Psychiatry, 24(3), 247-253. https://doi.org/10.3109/09540261.2012.678817

Hazen, E., Schlozman, S., \& Beresin, E. (2008). Adolescent psychological development: A review. Pediatrics in Review, 29(5), 161-167.

Kementerian Kesehatan Badan Penelitian dan Pengembangan Kesehatan. (2018). Hasil Utama Riskesdas. https://www.litbang.kemkes.go.id/hasil-utama-riskesdas-2018/

Maria, P., \& Evagelia, S. (2009). Obesity disease. Health Science Journal, 3(3), 132-138.

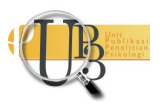


Mustofa, F. L., Husna, I., Hermawan, D., \& Langki, S. S. (2021). Gambaran angka kenaikan berat badan saat masa pandemi covid-19 pada mahasiswa angkatan 2017 fakultas kedokteran universitas malahayati. Jurnal Ilmu Kedokteran Dan Kesehatan, 8(1). https://doi.org/10.33024/jikk.v8i1.4026

Neuman, W. L. (2007). Basic of Social Research: Qualitative and Quantitative Approach. Pearson Education, Inc.

Presnell, K., Bearman, S. K., \& Stice, E. (2004). Risk factors for body dissatisfaction in adolescent boys and girls: A prospective study. International Journal of Eating Disorders, 36(4), 389-401. https://doi.org/10.1002/eat.20045

Rajkumar, R. P. (2021). Cross-national variations in covid-19 mortality: The role of diet, obesity and depression. Diseases, 9(2), 36. https://doi.org/10.3390/diseases9020036

Santrock, J. W. (2011). Life Span Development. 13th ed. New York: McGraw-Hill.

Schunk, D. H. (2005). Self-Regulated Learning: The Educational Legacy of Paul R. Pintrich. Educational Psychologist, 40(2), 85-94.

Susanti, I. N. (2015). Hubungan antara Social Comparison Tubuh dan Kecenderungan Ketidakpuasan Tubuh pada Anak Perempuan 8-11 Tahun [Universitas Sanata Dharma]. https://repository.usd.ac.id/54/

Winurini, S. (2020). Permasalahan kesehatan mental akibat pandemi covid-19. Kajian Singkat Terhadap Isu Aktual Dan Strategis, 12(15), 13-18.

World Health Organization. (2017). Depression and Other Common Mental Disorders: Global Health Estimates.

Zachary, Z., Brianna, F., Brianna, L., Garrett, P., Jade, W., Alyssa, D., \& Mikayla, K. (2020). Self-quarantine and weight gain related risk factors during the COVID-19 pandemic. Obesity Research \& Clinical Practice, 14(3), 210-216. https://doi.org/10.1016/j.orcp.2020.05.004 